\title{
Will our public healthcare sector fail the NHI?
}

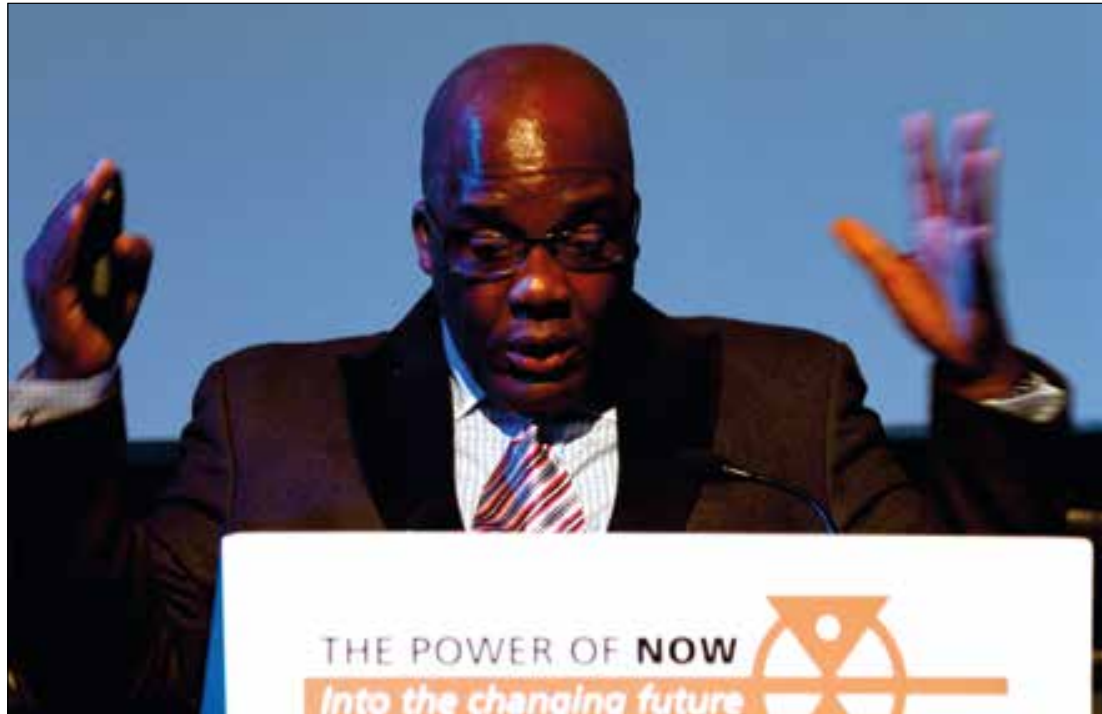

Dr Aaron Motsoaledi, National Minister of Health.

Feasible universal health coverage in South Africa seemed ever more remote last month as a dysfunctional Department of Public Works continued to stymie vital public hospital revitalisation projects, and five provinces proved grossly incapable of spending their health budgets.

\section{Motsoaledi told parliament that the national 'failure to} spend' was due to delays in the awarding of tenders, rolling over of budgets, poor performance of contractors (and the consequent termination of contracts and ensuing court challenges).

Alarming reports were tabled in parliament as international health policy experts at a nearby private Hospitals Association of South Africa (HASA) conference on Cape Town's Waterfront stressed how fundamental service quality and accessibility were to a feasible national health insurance (NHI) scheme. Responding to a parliamentary question, national health minister, Dr Aaron Motsoaledi, revealed that KwaZulu-Natal, the Eastern Cape, Free State, Limpopo and the Northern Cape had underspent their allocations to the hospital revitalisation programme by nearly R2 billion. In addition, preliminary findings of a high-level audit by his department found that most health facilities in the Eastern
Cape would have to close down once the current Norms and Standards Bill became law (findings in the four other sub-standard provinces are pending). Seasoned observers said a wholesale flouting of the law would be the only way the entire public healthcare system could avoid a crippling shut-down, with Eastern Cape health director-general, Dr Siva Pillay, dramatically illustrating the point ...

Pillay said six of his health institutions were already condemned but continued operating out of necessity, 168 clinics and 17 hospitals lacked piped water, 42 health facilities had no proper electricity and operated via generators, $68 \%$ of hospitals lacked essential medical equipment and $16 \%$ of facilities had no telephones and were accessible by road only in good weather. Overall staff vacancy rates stood at $46 \%$ (mostly clinical posts), requiring an unfeasible R9 billion extra to fill. 'The whole budget becomes almost a joke, he bluntly told the Parliamentary Health Portfolio Committee. None of his province's institutions could meet industry norms and standards and most buildings were not structurally sound enough to provide services - but operated anyway. The R1.1 billion allocated by Treasury this financial year towards improving infrastructure in his province would 'merely plaster the cracks' of a R20 billion infrastructure backlog while support services were 'in a dire' state. His department was embroiled in several court cases involving the alleged contamination of water sources as a result of poor sanitation at several facilities. A full $26 \%$ of his budget was going to infrastructure development, operations and maintenance - in spite of this being a local government (Public Works) function. Of the R1 billion needed for maintenance, only R150 million was allocated. Another R1.2 billion was required for vital equipment in the 856 clinics, 66 hospitals, 17 specialised hospitals and 10 additional hospitals which formed the three metropolitan health complexes. MPs at the sitting agreed that based on this information alone, the province was on the verge of healthcare collapse, and incapable of supporting a quality-based NHI hospital accreditation system. They cited a recent visit by the parliamentary health oversight committee to the Nessie Knight Hospital in the Eastern Cape. The MPs found its infrastructure to be dilapidated and recommended that the nurses' accommodation, the HIV/AIDS and TB wards and the generator room be demolished because of the health and safety risk they posed. The TB wards were poorly ventilated,the sanitation system needed upgrading and the sewerage system was dysfunctional.

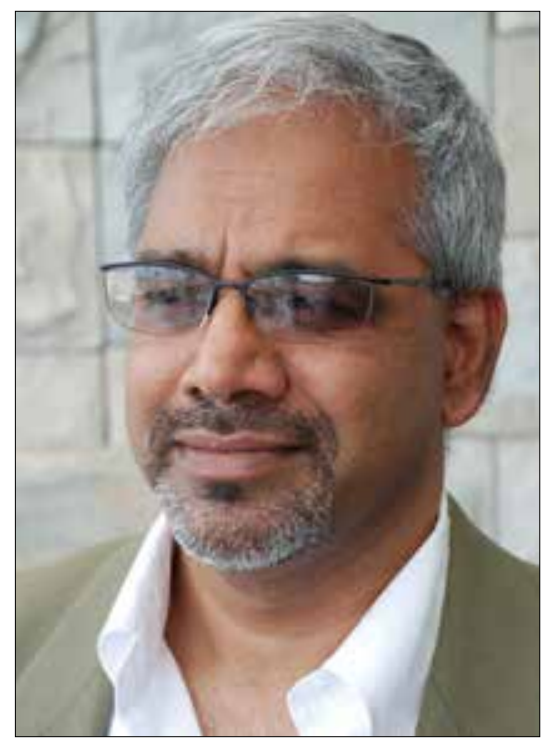

Dr Siva Pillay, Director-General, Eastern Cape Health Department.

\section{Tender delays and underperforming contractors}

Motsoaledi told parliament that the national 'failure to spend' was due to delays in the awarding of tenders, rolling over of budgets, poor performance of contractors (and the consequent termination of contracts 
and ensuing court challenges). This was echoed by the Eastern Cape Health Department spokesperson, Sizwe Kupelo, who said delays were caused by labour disputes and contractors not meeting their obligations. "We are not responsible for the appointment of contractors. Our core business is rendering health services, not infrastructure. When there are delays, we're equally frustrated, he complained. Kupelo said the Public Works Department and the (state-owned) Coega Development Corporation were responsible for such projects. According to its website, the Coega Development Corporation 'strives to improve the delivery of infrastructure in the Eastern Cape by addressing skills shortages, unemployment, constrained planning and project management capacity, underexpenditure, sub-standard infrastructure and inefficiencies that characterise delivery of infrastructure by government'.

Motsoaledi outlined the national underspending thus: Eastern Cape by R191 million (52\% underspend), KwaZulu-Natal by R228 million (full budget figure missing), the Free State by 134 million (35\%), Limpopo by R89 million (27\%) and the Northern Cape by R158 million (37\%). In addition to this the Eastern Cape underspent its HIV/ AIDS grant by R105 million and its forensic pathology budget by R14 million while Limpopo underspent its HIV/AIDS budget by R49.5 million and its forensic pathology budget by R1.2 million.

Speaking at the Cape Town International Convention Centre HASA conference, Dr Ravindra Rannan-Eliya, Director for Health Policy in Colombo, Sri Lanka, said that for an NHI to succeed in South Africa, public sector service quality and availability would need to 'at least' reach current medical scheme levels. Health professionals would also need large incentives to switch from the private to the public sector, a point picked up by Gyorgy Fritsche, the World Bank's Senior Health Specialist for the Africa Region. Fritsche said 'pay-for-performance' or results-based financing could be a powerful instrument in working towards universal health coverage. $\mathrm{He}$ cited monetary incentives to improve health coverage, including preventive services such as where doctors were paid extra for every vaccination performed. He said that elsewhere in Africa such incentives had drawn healthcare workers to remote areas where they focused on preventive health, sometimes boosting their salaries four-fold.

\section{Quality-based facility accreditation central to NHI}

Previous Izindaba interviews with both Dr Olive Shisana, Chairperson of the NHI ministerial advisory task team and Dr Carol Marshal, head of the Office for HealthCare Standards Compliance, established that qualitybased health facility accreditation is pivotal to the South African NHI model. Dr Marshal enthused about how for the first time public healthcare facilities would have to account for the quality of their services (and pit themselves against the competing private sector) to qualify for funds from the massive NHI pool.

Rannan-Eliya told HASA delegates that South Africa's existing public sector was an integrated delivery system, free at the point of delivery and not designed to receive extra-budgetary payments. 'There is no global experience of shifting free systems to insurance financing, he stressed, adding that cost control had proved unattainable globally without the use of monopoly funder power. He stressed that a full integration at the level of financing between the public and private sectors would be necessary. A transition to universal health coverage where everyone could access quality healthcare would be 'extraordinarily expensive'. However, the paradox was that without universal healthcare coverage, long-term cost control for both the fiscus and current private sector users would probably be impossible. Ultimately South Africans would need to decide how important it was for their society to pay the fiscal and political costs required to eliminate disparities in access to healthcare, he added.

\section{Too few left to do the job?}

A range of healthcare experts spoken to by Izindaba identified one of the core problems with the hospital revitalisation programme as being the dire lack of experienced engineers and architects available and willing to undertake public works projects. Tenders too often either went to politically connected individuals and/or under-qualified people with insufficient capacity to undertake, let alone complete the job. The lack of appropriate skills is illustrated in a nowdated but much-cited study by Meyer, Brown and Kaplan comparing StatsSA (official) data of South African immigrants to those of five major 'receiving countries (the United Kingdom, United States of America, Canada, Australia and New Zealand). The data from the receiving countries reported three times as many South Africans entering their borders than did the StatsSA data. Perhaps

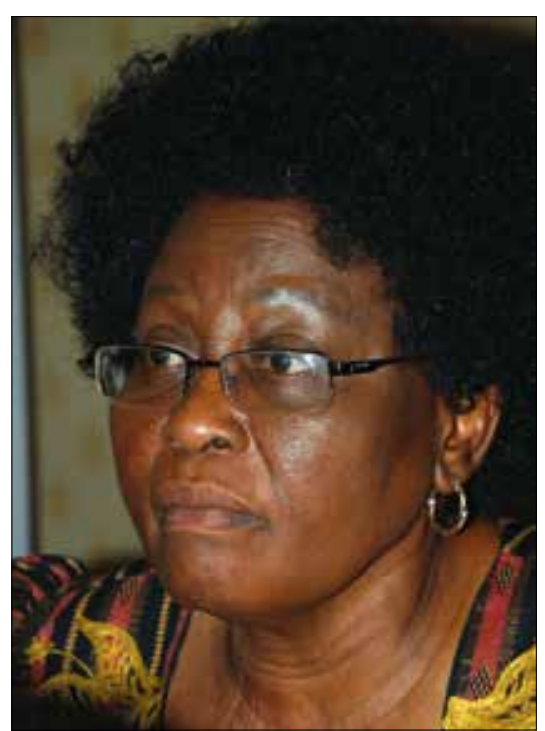

Dr Olive Shisana, Head of the NHI Ministerial Advisory Task Team.

more importantly, it showed that more than a quarter were skilled professionals. The study was conducted between 1987 and 1997 and published in 2000. According to the Genevabased International Labour Office's Migration Programme, South Africa is experiencing a 'deep and growing' skills shortage due to the emigration of skills 'with hardly any skilled immigration to balance the scale.'

Meanwhile, according to Erna Penning, Managing Director of iPAC, a Pretoriabased human risk solutions company, South Africa's rating on Transparency International's Corruption Perception Index dropped from 4.5 in 2010 to 4.1 last year. (In 2007 South Africa had a rating of 5.1.) Penning said this was the country's lowest rating since the index was started 17 years ago. The index has a 10-point scoring system. Penning described the trend as 'a precipitous slide' for any country to have, adding that if the rating dropped below 4, South Africa was headed for 'failed state' status where corruption was part of daily life and resulted in ever-increasing civil protests. 'We can't afford to let that happen because things can deteriorate rapidly into an "Arab Spring" scenario. It's time we get peeved off about corruption. We must put away the race card. This is about (all) our people. We must create an environment hostile to corruption, she added.

\section{Chris Bateman}

chrisb@hmpg.co.za 1. Bhorat H, Meyer J, Mlatsheni C. Developing Countries, a
Study on South and Southern Africa. International Migration
Programme, International Labour Office, Geneva. July 2002 .

$S$ Afr Med J 2012;102(11):817-818

DOI:10/7196/SAMJ.6358 